\title{
Milk cholesterol levels in relation to calcium soap and copper content in diets for dairy cows ${ }^{*}$
}

\author{
F. Brzóska and K. Sala \\ Research Institute of Animal Production, \\ Department of Feed Science and Animal Products \\ 32-083 Balice, Poland
}

\begin{abstract}
The experiment was conducted on 16 Red-and-White cows in a 2 × 2 Latin square design, using two levels of CaFA salts (without and with $6 \%$ salt in DM) and a low or high level of copper (13 vs $61 \mathrm{mg} \mathrm{Cu} / \mathrm{kg} \mathrm{DM}$ ). The cows were fed a grass-maize (1:1) silage and a concentrate given in the amount of $0.28 \mathrm{~kg} / \mathrm{kg}$ milk yield. DM intake averaged $16.79 \pm 0.15 \mathrm{~kg}$, including $10.63 \pm 0.12 \mathrm{~kg}$ from silage and $6.18 \pm 0.14 \mathrm{~kg} / \mathrm{d}^{-1}$ from the concentrate. The average FCM milk yield was $22.84 \pm 0.54 \mathrm{~kg} / \mathrm{d}^{-1}$ with $4.11 \pm 0.44 \%$ fat, $3.01 \pm 0.33 \%$ protein and $5.36 \pm 0.34 \%$ lactose contents. A significant $(\mathrm{P}=0.028)$, negative effect of copper on the fat content of milk was found, whereas CaFA salts had a positive effect on the daily synthesis of fat and protein. The total cholesterol content in milk equaled $13.64 \pm 0.40$ $\mathrm{mg} / 100 \mathrm{~g}$ and did not differ significantly at the levels of CaFA or copper used in the diet. Fceding cows CaFA salts lowered the level of saturated fats in milk (capric (C10), lauric (C12), myristic (C14) and palmitic ( $\mathrm{Cl}$ ) acids), and raised the level of stearic (C18) and alpha-linolenic (C18:3, $\mathrm{n}-3)$ acids. The higher level of copper significantly $(\mathrm{P}=0.0001)$ increased the content of oleic acid (C 18:1) in milk. Feeding cows CaFA increased the level of unsaturated fatty acids (UFA, MUFA) in milk in a highly significant manner, as did higher doses of copper $(\mathrm{P}=0.0001)$. The level of fatty acids exhibiting hypocholesterolemic properties (DFA) increased from 40.86 to $46.85 \%$ under the influence of CaFA and from 43.14 to $44.57 \%$ under the influence of copper.
\end{abstract}

KEY WORDS: calcium FA salts (CaFA), copper, cholesterol, cows

\section{INTRODUCTION}

The cholesterol content of milk averages in the range of $8-13 \mathrm{mg} / 100 \mathrm{~g}$. It is much higher in dairy products, ranging from 30 to $120 \mathrm{mg} / 100 \mathrm{~g}$ (Buliński and Szydłowska, 1971). The milk cholesterol content decreases slightly as lactation

* Supported by the State Committee for Scientific Research, Grant No. P06E 02018 
progresses, as well as with the age of cows (Bohac and Rhee, 1988). The heritability index of cholesterol in milk is estimated at about 0.10 (Skrzypek, 1999). Dietary guidelines for humans consider cholesterol to be unnecessary, or even harmful. The low density lipid (LDL) fraction of cholesterol is involved in pathological changes and causes atherosclerotic lesions in the blood vessels, leading to cardiac ischemia. The cholesterol found in dairy products accounts for $50-60 \%$ of the cholesterol consumed by adults. Dietary guidelines for humans specify $300 \mathrm{mg} /$ day as the maximum allowed consumption of exogenous cholesterol, as compared with the endogenous synthesis of this compound in the liver of $1500 \mathrm{mg} /$ day (NCEP, 1990; USDA, 1990). Oxidation products of cholesterol, oxysterols, found in milk are also harmful.

In studies on laboratory animals it was found that dietary copper and zinc levels also affect lipid metabolism, including that of cholesterol (Mazur et al., 1993; Rayssiguier et al., 1993). It was shown that mice and rats with advanced vascular arteriosclerosis had a very low level of copper in the blood, which suggests that hypocupremia is one of the factors promoting arteriosclerosis. Earlier studies have shown that a deficit of copper in the diet leads to changes in the function of hepatic enzymes, including lowering the activity of enzymes responsible for cholesterol metabolism (Lei, 1991).

A study was undertaken on cows to examine the effect of a varied level of calcium salts of fatty acids (CaFA) and two levels of copper within each level of fat in the ration on blood and milk cholesterol levels and on the yields, contents and daily synthesis of components. In this study, a working hypothesis was adopted that a varied level of copper in the diet for cows will, through influencing liver metabolism, significantly affect plasma and milk cholesterol levels.

\section{MATERIAL AND METHODS}

The study was conducted on 16 Red-and-White cows in a double $2 \times 2$ Latin square design, with two levels of CaFA and two levels of copper in the ration. The copper level was adjusted by adding anhydrous copper oxide to the mineral mixture in the amount of 13-14 (low dose) and $60-61 \mathrm{mg} / \mathrm{kg}$ (high dose) of DM consumed. The daily intake of copper was, respectively, 0.228 and $1.018 \mathrm{~g} / \mathrm{cow} /$ day. The zinc level (in the form of hydrated zinc sulphate) was maintained at a constant level of $37.50 \mathrm{mg} / \mathrm{kg} \mathrm{DM}$ of the ration, which is the equivalent of an intake of $1.629 \mathrm{~g} \mathrm{Zn} / \mathrm{cow} /$ day and the daily requirement for zinc (MAFF, 1984; Rogers, 1996). CaFA salts in the form of the modified feed fat, Erafet, were made using rape seed and fish oils and animal fat at a proportion of 3.5:0.5:6.0. The salts were supplied in the feed in an amount equal to $6 \%$ of daily dry matter intake, which is the equivalent of about $936 \mathrm{~g}$ of Erafet feed fat/cow/day. The cows were fed $a d$ 
libitum with a grass-maize silage and a feed concentrate provided in the amount of $0.28 \mathrm{~kg} / \mathrm{kg}$ milk yield. Bovimix (BASF, Kutno, Poland) mineral mixture containing mineral components including the appropriate amounts of copper and zinc were given to cows in the amount of $80 \mathrm{~g} / \mathrm{cow} /$ day. Cows were fed according to IZ-INRA standards (1993). Every 21 -day experimental period comprised 18 days of adaptation and 3 days of sampling. Blood was sampled from the jugular vein, enzyme activity and biochemical parameters were determined in the plasma.

The milk yield of cows was expressed as standard milk with a $4 \%$ fat (FCM, $\mathrm{kg} / \mathrm{d}$ ) and $3 \%$ protein content $(\mathrm{FCP}, \mathrm{kg} / \mathrm{d})$. The content of nutrients in feeds was determined using conventional methods (AOAC, 1990). Feed dry matter was determined at $105^{\circ} \mathrm{C}$, and its content in silages was adjusted for the level of volatile substances (Dulphy and Demarquilly, 1981). Fatty acids in milk were determined as methyl esters of acids using a GLC Varian 3400 gas chromatograph with a DB-FFAP column and the method described by Atwala et al. (1990). The fat, protein and lactose contents in milk, renneting time, density and $\mathrm{pH}$ were determined in accordance with Polish Standards (PN 68/A-86122). Mineral components in milk were determined by atomic absorption spectrometry using a Philips apparatus after mineralizing of samples in a MEGA-1200 microwave oven.

The results were subjected to statistical analysis using factorial two-way factorial analysis of variance. Average values for the particular rations with and without added fat and with high and low amounts of copper were compared by Student's t-test using Statgraphics 6.0 software.

\section{RESULTS AND DISCUSSION}

Effect of CaFA salts $(\mathrm{P}=0.26)$ and copper $(\mathrm{P}=0.17)$ on milk yield was not significant appeared to be statistically. In the ration without added fat, supplemented . copper significantly increased milk yield, while in fat-supplemented rations, it decreased milk yield. Adding CaFA significantly lowered the milk fat content $(\mathrm{P}=0.03)$ and significantly increased the lactose content $(\mathrm{P}=0.001)$, whereas it had no effect on protein content. Giving cows increased doses of copper significantly reduced the fat $(\mathrm{P}=0.0004)$ and protein $(\mathrm{P}=0.05)$ levels, while it only slightly increased the lactose level in milk. It was found that higher amounts of copper in the ration significantly decreased the level of milk fat $(\mathrm{P}=0.0004)$. This indicates that that copper is involved in the synthesis of milk fat and that its excess inhibits this process.

The average total cholesterol value in milk was $13.64 \pm 0.40 \mathrm{mg} / 100 \mathrm{ml}$, and no significant influence of providing CaFA salts and copper to cows was found on the cholesterol level in milk. Copper level did not effect significantly the cholesterol concentration in blood plasma. This fact contradicts the working hypothesis that 
by inhibiting hepatic reactions, the differentiated level of copper in the diet of cows, especially the lower level, reduces hepatic cholesterol synthesis and lowers both plasma and milk cholesterol levels. The relatively high total cholesterol content in the milk of cows in all of the groups indicates that providing copper at about $13 \mathrm{mg} / \mathrm{kg} \mathrm{SM}$ and higher is not a factor lowering the total cholesterol level in milk.

A significant effect of copper $(\mathrm{P}=0.011)$ in rations on the level of this element in milk was found. This effect was significant in the rations without added CaFA. This indicates that giving cows rations with an excessive copper content may significantly increase the level of this element in milk.

The results of this study showed that adding CaFA to rations in an amount equal to $6 \%$ of DM increases the polyunsaturated fatty acid content in milk fat, including MUFA ( $\mathrm{P}=0.0001)$, while simultaneously reducing the content of saturated fatty acids, which improves the dietary value of milk. The synthesis of such short-chain saturated fatty acids as capric $(\mathrm{C} 10)$, lauric $(\mathrm{Cl} 2)$, myristic $(\mathrm{Cl})$ and palmitic $(\mathrm{C} 16)$ acids is reduced $(\mathrm{P}=0.001)$.

The study carried out by us shows that applying highly differentiated levels of copper (at levels equal to and much in excess of requirements) in rations for cows does not significantly affect total blood cholesterol. A copper content of $13-14 \mathrm{mg} /$ $\mathrm{kg} D M$ in rations meets the requirement for this element, whereas $60-61 \mathrm{mg} / \mathrm{kg}$ DM is much in excess (MAFF, 1984; Rogers, 1996). The elevated level of copper in the rations significantly reduces plasma low-density cholesterol (LDL) levels, but this does not have an effect on total milk cholesterol levels.

\section{CONCLUSIONS}

Differentiated copper levels of 13 to $61 \mathrm{mg} / \mathrm{kg} \mathrm{DM}$ in rations for dairy cows do not significantly affect milk yield, but do lower the fat and protein contents of milk, including casein and whey proteins. The amounts of copper administered did not affect the total cholesterol content in milk over $13 \mathrm{~g} / 100 \mathrm{~g}$, which given its high plasma level, indicates that there are cholesterol level receptors in the mammary gland. The intake of copper in the amounts given above increases the content of monounsaturated fatty acids, mainly oleic acid, and the sum of unsaturated fatty acids in milk and lowers plasma LDL cholesterol, but does not affect the total cholesterol level in milk.

Calcium salts of fatty acids fed in the amount of $6 \%$ of the DM of the ration increase the milk yield of cows and lower the fat and lactose levels of milk. Fat in the form of CaFA salts increases the content of monounsaturated fatty acids and $\alpha$-linolenic acid (C18:3, n-3) in milk fat, which improves the dietary value of milk. 


\section{REFERENCES}

AOAC, 1990. Official Methods of Analysis. Association of Official Analytical Chemists. 15th Edition. Arlington, VA

Atwal A.S., Hidiroglou M., Kramer J.K.G., Binns M.R., 1990. Manipulation of the fatty acids composition of milk by feeding protected canola seeds. J. Dairy Sci. 75, 1090-1096

Bohac C.E., Rhee K.S., 1988. Inthuence of animal diet and muscle location on cholesterol content of beef and pork muscles. Meat Sci. 23, 71-75

Buliński R., Szydtowska E., 1971. Free cholesterol content in products of animal origin. Bromat. Chem. Toksykol. IV (1), 59-65

Dulphy J.P., Demarquilly C., J981. Problems particuliers aux ensilages, prevision de la valuer nutritive des aliments des ruminants. INRA Publ., pp. 81-104

Gocring 11.R., van Soest P.J., 1970. Forage Fiber Analysis. Agriculture Handbook, No. 379, USDA, Washington

Klevay L.M., 1973. Hypercholesterolemia in rats produced by an increase in the ratio of zinc to copper ingested. Amer. J. Clin. Nutr. 26, 1060-1068

Lei K.Y., 1991. In: Role of copper in lipid metabolism. K.Y. Lei (Editor). CRS Press, Boca Raton, pp. $1-23$

MAFF, DAFS, DANI, UKASTA, BVA Working Party Report, 1984. Mineral, trace element and vitamin allowances for ruminant livestock. W. Haresign, J.A. Cole (Editors). In: Recent Advances in Animal Nutrition. Butterwortlss, pp. 113-143

Mazur A., Nassir F., Gueux E., Rayssiguier Y., 1993. Plasma lipoproteins and apolipoproteins in copper deficient rats: studies on apolipoprotein synthesis and gene expression. In: Trace Element in Man and Animals - TEMA 8. A. Anke, D. Meissner, C.F. Mills (Editors), pp. 525-529

National Cholestcrol Education Program, 1990. Report of the Expert Panel on Population Strategies for Blood Cholesterol Reduction. USD Health Human Serv., Natl. Inst. Health No. 90-3046, Washington, DC

Polish Standards (PN 68/A-86122). Analytical Methods

Rayssiguier Y., Gueux E., Motta C., Mazur A., 1993. Effect of copper deficiency in rats on lipoprotein and tissue peroxidation. In: Trace Element in Man and Animals - TEMA 8. A. Anke, D. Meissner, C.F. Mills (Editors), pp. 530-534

Rogers P.A.M., 1996. Effective oral trace-element supplements for cattle and sheep. Teagasc, Grange research Centre, Dunsany, Co. Mcath, pp. 1-14

Skrzypek R., 1999. Effect of feed fat on consumers health, quality of cows milk fat and beef. In: Cattle Production in Different Conditions. Cracow Agriculture University Press, pp. 246-269

USDA, Dep. of Health and Human Services, 1990. Nutrition and your Health: dietary guidelines for Americans. $3^{\text {rd }}$ Edition. Washington, DC 


\section{STRESZCZENIE}

\section{Zawartość cholesterolu w mleku krów w zależności od udzialu soli wapniowych kwasów tluszczowych i miedzi w diecie}

W doświadczeniu użyto 16 krów rasy czb, w układzie kwadratu łacińskiego 2 x 2, z dwoma poziomami soli CaFA (bez i z dodatkiem $6 \%$ soli CaKT w SM) oraz z niskim i wysokim poziomem miedzi (13 vs $61 \mathrm{mg} \mathrm{Cu} / \mathrm{kg} \mathrm{SM}$ ). Krowy żywiono kiszonką z traw i kukurydzy do woli oraz mieszanką paszową podawaną w ilości $0,3 \mathrm{~kg} / \mathrm{kg}$ uzyskanego mleka. Pobranie SM wynosiło średnio $16,79 \pm 0,15 \mathrm{~kg}$, w tym $10,63 \pm 0,12 \mathrm{~kg}$ kiszonki, przy zużyciu $6,18 \pm 0,14 \mathrm{~kg} / \mathrm{d}^{-1}$ mieszanki paszowcj. Średnia wydajność mleka FCM wynosiła $22,84 \pm 0,54 \mathrm{~kg} / \mathrm{d}^{-1}, z$ zawartością $4,11 \pm 0,44 \%$ tłuszczu, $3,01 \pm 0,33 \%$ białka i $5,36 \pm 0,34 \%$ laktozy. Stwierdzono statystycznic istotny, ujemny wpływ miedzi na zawartość tłuszczu w mleku, przy dodatnim wplywie soli CaKT na wielkość syntezy dobowej thuszczu i białka. Zawartość cholesterolu całkowitego w mleku wynosiła $13,64 \pm 0,40 \mathrm{mg} / 100 \mathrm{~g}$ i nie różnila się istotnie dla poziomu soli CaKT oraz poziomu miedzi w dawce pokarmowej. Podawanie krowom soli CaKT istotnie obniżyło w mleku zawartość kwasów nasyconych, kaprynowego (Cl0), laurynowego (C12), mirystynowego (C14) i palmitynowego (C16), a podwyższyło zawartość kwasu stearynowego (C18) i $\alpha$-linolenowego (C18:3, n-3). Wyższy poziom miedzi istotnie zwiększył zawartość kwasu oleinowego (C 18:1) w mleku. Podawanie krowom soli CaKT wysoce istotnie, a większych dawek miedzi istotnie zwiększyło poziom kwasów nienasyconych (UFA, MUFA) w mleku. Zwiększył się w mleku poziom kwasów o działaniu hipocholesterolemicznym (DFA), od 40,86 do $46,85 \%$, pod wpływem soli CaKT oraz od 43,14 do $44,57 \%$ pod wpływem miedzi. 